\title{
Nitrous oxide emission from upland soil amended with different animal manures
}

\author{
Sung Un Kim ${ }^{1}$, Chuanpit Ruangcharus ${ }^{1}$, Sandeep Kumar ${ }^{2}$, Hyun Ho Lee ${ }^{1}$, Hye Jin Park ${ }^{1}$, Eun Sang Jung ${ }^{3^{*}}$ \\ and Chang Oh Hong ${ }^{1,4^{*}}$
}

\begin{abstract}
The nitrous oxide $\left(\mathrm{N}_{2} \mathrm{O}\right)$ emission of from arable soil following the application of manure is expected to vary by different animal manure types used. This study was conducted to determine the relationship between the type of animal manure used to amend soil and the amount of $\mathrm{N}_{2} \mathrm{O}$ emitted during the cultivation of sweet potato (Ipomoea batatas). An additional objective was to study the characteristics of nitrogen $(\mathrm{N})$ and carbon $(\mathrm{C})$ in different animal manures. Composted manures from chickens, cows, and pigs were applied to the soil at rates of 0,10 , and $20 \mathrm{Mg} \mathrm{ha}^{-1}$, respectively. The availability and concentration of $\mathrm{N}$ and $\mathrm{C}$ varied by manure type. The concentration of $\mathrm{NH}_{4}^{+}$was greater in pig manure (4638 $\mathrm{mg} \mathrm{kg}^{-1}$ ) than in chicken $\left(551 \mathrm{mg} \mathrm{kg}^{-1}\right)$ and cow manure $\left(147 \mathrm{mg} \mathrm{kg}^{-1}\right)$. The mean cumulative $\mathrm{N}_{2} \mathrm{O}$ emission rate across soil application rates was also the highest with pig manure $\left(11.9 \mathrm{~kg} \mathrm{ha}^{-1} \mathrm{year}^{-1}\right)$, followed by chicken and cow manure, with emission rates of 10.8 and $10.1 \mathrm{~kg} \mathrm{ha}^{-1}$ year ${ }^{-1}$, respectively. The majority of $\mathrm{N}_{2} \mathrm{O}$ measured during the sweet-potato-growing season was produced from aerobic nitrification. Dissolved organic carbon (DOC) concentrations in animal manures did not affect cumulative $\mathrm{N}_{2} \mathrm{O}$ emission rates, and no significant relationship was observed throughout the growing season between the concentration of DOC in soil and daily $\mathrm{N}_{2} \mathrm{O}$ emission. Cumulative $\mathrm{N}_{2} \mathrm{O}$ emission rates depended on the type of animal manure and might be governed by $\mathrm{NH}_{4}{ }^{+}$concentration, rather than by total $\mathrm{N}$ concentration in animal manure type.
\end{abstract}

Keywords: Denitrification, Greenhouse gas, Nitrification, Nitrogen use, Sweet potato

\section{Introduction}

Nitrous oxide $\left(\mathrm{N}_{2} \mathrm{O}\right)$ is one of greenhouse gases that destroys ozone layer in the stratosphere. Predictive models suggest that atmospheric $\mathrm{N}_{2} \mathrm{O}$ may increase from the present concentration of $328 \mu \mathrm{g} / \mathrm{L}$ up to $354-460 \mu \mathrm{g} / \mathrm{L}$ by 2100 (IPCC 2013). Agricultural soil that incorporates nitrogen $(\mathrm{N})$ fertilizer is a major source of $\mathrm{N}_{2} \mathrm{O}$, accounting for approximately $4.3-5.8 \mathrm{Tg} \mathrm{N}_{2} \mathrm{O}-\mathrm{N}$ year ${ }^{-1}$, which is $23-31 \%$ of the global annual emission [1].

Atmospheric $\mathrm{N}_{2} \mathrm{O}$ is emitted from soils by the microorganisms associated with nitrification and denitrification after the application of $\mathrm{N}$ fertilizer and organic matter such as manure, compost, and peat moss. The application

\footnotetext{
*Correspondence: esjung@pusan.ac.kr; soilchem@pusan.ac.kr ${ }^{1}$ Department of Life Science and Environmental Biochemistry, Pusan National University, Miryang 50463, Republic of Korea

${ }^{3}$ Department of Bioenvironmental Energy, Pusan National University, Miryang 50463, Republic of Korea

Full list of author information is available at the end of the article
}

of organic matter increases the $\mathrm{N}$ and carbon $(\mathrm{C})$ sources necessary for nitrification and denitrification, respectively [2,3], while microbial activity is enhanced, $\mathrm{O}_{2}$ is consumed, and anaerobic microsites can develop [4].

Many researchers have reported that the amendment with organic matter could significantly increase $\mathrm{N}_{2} \mathrm{O}$ emissions from arable soil [5-13]. Several factors have been identified that affect the $\mathrm{N}_{2} \mathrm{O}$ emission from arable soils, including the $\mathrm{N}$ fertilization [12-16], $\mathrm{pH}[17,18]$, soil moisture, and temperature $[19,20]$. In particular, the content and availability of $\mathrm{N}$ and $\mathrm{C}$ in organic matter could be one important factor affecting $\mathrm{N}_{2} \mathrm{O}$ emission from arable soil. Huang et al. [8] reported the cumulative emission of $\mathrm{N}_{2} \mathrm{O}$ was negatively correlated with the C:N ratio in plant residues and positively correlated with dissolved organic carbon (DOC) concentration. As a specific fraction of soil organic carbon, DOC represents the easily degradable portion that is available to microorganisms $[21,22]$. Both $\mathrm{N}_{2} \mathrm{O}$-producing processes (nitrification 
and denitrification) are directly controlled by the supply of inorganic $\mathrm{N}$ substrates $\left(\mathrm{NH}_{4}{ }^{+}\right.$and $\left.\mathrm{NO}_{3}{ }^{-}\right)$[23].

Emissions of $\mathrm{N}_{2} \mathrm{O}$ from manure-amended fields will vary with animal type due to differences in diet, feed conversions, and management of the manure that result in differences in composition of components such as $\mathrm{N}$ and C. Several laboratory-based studies demonstrated the influence of manure type on $\mathrm{N}_{2} \mathrm{O}$ emission from soil [24, 25]. However, these experiments were conducted in the absence of plants. Additionally, few studies have been conducted that compare $\mathrm{N}_{2} \mathrm{O}$ emission rates from field soil amended with manure from different types of livestock. Therefore, this study was conducted to determine the relationship between the amount of $\mathrm{N}_{2} \mathrm{O}$ emitted from soil amended with animal manure (especially, chicken, cow, and pig) under field conditions, and to characterize $\mathrm{N}$ and $\mathrm{C}$ in the different animal manures.

\section{Materials and methods}

\section{Site description and characteristics of manure}

The study was conducted on an experimental farm operated by Pusan National University, Miryang, Korea $\left(35^{\circ} 30 \mathrm{~N}, 128^{\circ} 43 \mathrm{E}\right)$. The farm's upland soil belongs to the Bongsan series (fine loamy, mixed, mesic family of Typic Hapludults), and is moderately well-drained with a 7-15\% slope. Soil pH was 6.4 and total $\mathrm{N}$ concentration was $1.05 \mathrm{~g} \mathrm{~kg}^{-1}$. Specific physical and chemical properties of the studied soil are shown in Table 1 . Precipitation and temperature data were obtained from a weather station in Miryang (Korea Meteorological Administration), located $1 \mathrm{~km}$ from the study site.

Composted chicken, cow, and pig manure were used in this study:

\section{Table 1 Selected characteristics of the studied soil}

\begin{tabular}{|c|c|}
\hline Parameters & Value \\
\hline \multicolumn{2}{|l|}{ Soil separate } \\
\hline Sand (\%) & 43.4 \\
\hline Silt (\%) & 44.5 \\
\hline Clay (\%) & 12.1 \\
\hline Soil texture & Loam \\
\hline Bulk density $\left(\mathrm{g} \mathrm{cm}^{-1}\right)$ & 1.34 \\
\hline $\mathrm{pH}\left(1: 5\right.$ with $\left.\mathrm{H}_{2} \mathrm{O}\right)$ & 6.4 \\
\hline Organic matter $\left(\mathrm{g} \mathrm{kg}^{-1}\right)$ & 15.6 \\
\hline Total nitrogen $\left(\mathrm{g} \mathrm{kg}^{-1}\right)$ & 1.05 \\
\hline Available phosphate $\left(\mathrm{mg} \mathrm{kg}^{-1}\right)$ & 142 \\
\hline \multicolumn{2}{|l|}{ Exchangeable cation } \\
\hline $\mathrm{K}\left(\mathrm{cmol}_{\mathrm{c}} \mathrm{kg}^{-1}\right)$ & 0.42 \\
\hline $\mathrm{Ca}\left(\mathrm{cmol}_{\mathrm{c}} \mathrm{kg}^{-1}\right)$ & 5.76 \\
\hline $\mathrm{Mg}\left(\mathrm{cmol}_{\mathrm{c}} \mathrm{kg}^{-1}\right)$ & 1.25 \\
\hline
\end{tabular}

Table 2 Chemical properties of composted animal manures used in this study

\begin{tabular}{|c|c|c|c|c|c|}
\hline Manure & $\begin{array}{l}\mathrm{T}-\mathrm{N} \\
\left(\mathrm{g} \mathrm{kg}^{-1}\right)\end{array}$ & $\begin{array}{l}\mathrm{NH}_{4}^{+} \\
\left(\mathrm{mg} \mathrm{kg}^{-1}\right)\end{array}$ & $\begin{array}{l}\mathrm{NO}_{3}^{-} \\
\left(\mathrm{mg} \mathrm{kg}^{-1}\right)\end{array}$ & $\begin{array}{l}\mathrm{T}-\mathrm{C} \\
\left(\mathrm{g} \mathrm{kg}^{-1}\right)\end{array}$ & $\begin{array}{l}\text { DOC } \\
\left(\mathrm{mg} \mathrm{kg}^{-1}\right)\end{array}$ \\
\hline Chicken & 18.0 & 551 & 4.83 & 425 & 1271 \\
\hline Cow & 7.90 & 147 & 120 & 309 & 460 \\
\hline Pig & 13.9 & 4638 & 3.97 & 540 & 204 \\
\hline
\end{tabular}

$T-N$ total nitrogen, $T-C$ total organic carbon, $D O C$ dissolved organic carbon

1. Chicken manure was obtained from a commercial broiler farm (Synnong Fertilizer). It contained bark, husk, sawdust, rice bran, dolomitic limestone, and a leavening agent.

2. Cow manure was obtained from a farming association article of incorporation. It contained sawdust, wood chips, and a leavening agent.

3. Pig manure was obtained from a commercial pig farm (JG Bio). It contained sawdust.

Specific characteristics of each manure are shown in Table 2.

\section{Field experiment}

A field experiment was conducted to determine if animal manure type and application rate impacted $\mathrm{N}_{2} \mathrm{O}$ emission from arable soil. Three composted animal manures (chicken, cow, and pig) were applied to small plots $(2.5 \mathrm{~m} \times 4 \mathrm{~m})$ at rates of 0,10 , and $20 \mathrm{Mg} \mathrm{ha}^{-1}$, respectively. All manures were incorporated into the soil using moldboard plows 2 weeks before transplanting sweet potato (lpomoea batats) to the field on May 20 , 2016. Plant spacing within rows was $20 \mathrm{~cm}$. Inorganic fertilizers in the form of urea, fused phosphate, and potassium sulfate were applied to all plots 2 days after transplanting on June 6, 2016. Experimental plots were arranged in a randomized complete block design with four replications. Sweet potatoes were harvested on October 1, 2016. Weeds were removed from plots by hand throughout the growing season.

\section{Measurement of $\mathrm{N}_{2} \mathrm{O}$ emission}

Soil surface $\mathrm{N}_{2} \mathrm{O}$ flux was measured from 44 plots (control, three animal manures, and two application rates replicated four times) once every 2 weeks during the sweet-potato-growing season (May 2016 through October 2016), and once every month during the fallow season (November 2016 through May 2017) using the static chamber technique [26]. Static chambers made of PVC pipe $(24.8 \mathrm{~cm}$ diameter $\times 15 \mathrm{~cm}$ height $)$ were installed at the center of each plot before application of 
animal manures and inorganic fertilizers. The chambers remained in place during completely year round both the growing season and the fallow season. Before taking gas samples, a PVC cap with a vent tube and sampling port were placed on the anchors. Gas that accumulated inside the chamber was collected with a $20 \mathrm{ml}$ syringe at 0,20 , and $40 \mathrm{~min}$. The gas samples were transferred from the syringe into $12 \mathrm{ml}$ evacuated glass vials (Exetainer $^{\circledR} 12 \mathrm{ml}$ vial-evacuated $838 \mathrm{~W}$, Labco, Wales, UK.) sealed with butyl rubber septa. Concentrations of $\mathrm{N}_{2} \mathrm{O}$ were measured using a Gas Chromatograph (Shimadzu GC-2010 plus) with a Porapak Q (80/100 mesh) column and an electron capture detector. The highest grade of prefiltered $\mathrm{N}_{2}$ was the carrier gas. Calibration was routinely performed using dilutions of a certified gas standard mix (Scott Specialty Gases, Plumsteadville, PA, USA). For quality assurance, four replicated samples were injected and measured.

Daily gas flux (F, g ha ${ }^{-1}$ day $^{-1}$ ) was calculated as the follows:

$$
F=(\Delta g / \Delta t) \times d \times(273 / T) \times(V / A) \times k \times a
$$

where $\Delta g / \Delta t$ is the linear change in gas concentrations inside the chamber $\left(\mathrm{g} \mathrm{m}^{-3} \mathrm{~min}^{-1}\right), d$ is gas density $\left(\mathrm{g} \mathrm{m}^{-3}\right)$ at $273 \mathrm{~K}$ and $0.101 \mathrm{MPa}$ pressure, $T$ is the air temperature $(\mathrm{K})$ within the chamber, $V$ is the chamber volume $\left(\mathrm{m}^{3}\right), A$ is the surface area circumscribed by the chamber $\left(\mathrm{m}^{2}\right), k\left(\mathrm{~min} \mathrm{day}^{-1}\right)$ is the time conversion coefficient, and $a\left(10,000 \mathrm{~m}^{2} \mathrm{ha}^{-1}\right)$ is the area conversion coefficient. Soil moisture and temperature were measured on a volumetric basis using a 5TE moisture sensor (Decagon Devices, Pullman, WA, USA) every $2 \mathrm{~h}$ during whole experiment period. Air temperature was measured in the chamber at the time of gas sampling and used to calculate $\mathrm{N}_{2} \mathrm{O}$ fluxes.

\section{Physical and chemical analysis}

The water-filled pore space (WFPS, \%) was calculated every day for a year using the equation below:

$$
\text { WFPS }=(\theta / \text { soil porosity }) \times 100
$$

where $\theta$ is the volumetric moisture content $\left(\mathrm{m}^{3} \mathrm{~m}^{-3}\right)$. Soil porosity $\left(\mathrm{m}^{3} \mathrm{~m}^{-3}\right)$ was calculated using a particle density value of $2.65 \mathrm{Mg} \mathrm{m}^{-3}$, and soil bulk density values measured once every month of the study period. Averaged daily volumetric moisture was measured at $5 \mathrm{~cm}$ soil depth using a soil moisture sensor (WT1000B, RF sensor, Seoul, Korea) installed in each plot.

Soil samples were also collected from each plot once in every month during the sweet-potato-growing season for analysis of inorganic $\mathrm{N}\left(\mathrm{NH}_{4}{ }^{+}\right.$and $\left.\mathrm{NO}_{3}{ }^{-}\right)$. Air-dried soil samples $(5 \mathrm{~g})$ were extracted using $50 \mathrm{~mL}$ of $2 \mathrm{M} \mathrm{KCl}$.
After shaking for $1 \mathrm{~h}$, the samples were filtered through Whatman no. 5 filters and the extracts were analyzed using automated colorimetry [27, 28]. In addition, $5 \mathrm{~g}$ of wet soil samples were centrifuged at $6000 \mathrm{rpm}$ for $15 \mathrm{~min}$ to remove the pore water. The supernatant liquid was separated using a $0.45-\mu \mathrm{m}$ membrane filter and was then measured for DOC concentration [29]. DOC was quantified with a total organic carbon (TOC) analyzer (Model TOC-VCPN; Shimadzu, Japan).

\section{Nitrogen-use of sweet potato}

$\mathrm{N}$ use of sweet potato was determined using manure $\mathrm{N}$ removal (MNR) and apparent $\mathrm{N}$ recovery (ANR).

The total $\mathrm{N}$ removal was calculated by multiplying the total dry matter yield of sweet potato by the $\mathrm{N}$ concentration on dry matter base. The MNR was calculated by subtracting the total $\mathrm{N}$ removal from the control $\left(0 \mathrm{Mg} \mathrm{ha}^{-1}\right)$ from total $\mathrm{N}$ removal from the manure-applied treatments $\left(10\right.$ or $\left.20 \mathrm{Mg} \mathrm{ha}^{-1}\right)$ [30].

ANR (\%) for each harvest was calculated as [30]:

$\mathrm{ANR}=[$ (mass of $\mathrm{N}$ removed at application rate

- mass of $\mathrm{N}$ removed at control)

/mass of $\mathrm{N}$ applied at application rate $] \times 100$

\section{Statistical analysis}

All statistical analyses were performed using Statistix version 9.0 (Statistix 2008). Mean values of cumulative $\mathrm{N}_{2} \mathrm{O}$ emission, inorganic $\mathrm{N}$ and DOC concentrations in soil, MNR, and ANR were analyzed by conducting pairwise comparisons. A least significant difference was used to separate mean effects when the appropriate $\mathrm{F}$ test was significant $(p<0.05)$.

\section{Results and discussion}

Daily $\mathrm{N}_{2} \mathrm{O}$ flux was measured for 1 year (Fig. 1a) to examine the association of $\mathrm{N}_{2} \mathrm{O}$ emission with application rate and type of animal manure. $\mathrm{N}_{2} \mathrm{O}$ fluxes peaked in May and June and then decreased dramatically from July onward. Similar findings were observed in dairy manure and inorganic fertilizer application in corn and soybean rotation [31]. The first and second $\mathrm{N}_{2} \mathrm{O}$ peaks appeared soon after application of animal manures and inorganic $\mathrm{N}$ fertilizer, respectively. Animal manures were applied on 20th May and the first $\mathrm{N}_{2} \mathrm{O}$ peak took place 6 days later on 26th May. Although the mineralization rate of organic $\mathrm{N}$ in manure depends on aeration, moisture condition, and microbial activity in the soil, the release of inorganic $\mathrm{N}\left(\mathrm{NH}_{4}{ }^{+}\right.$and $\left.\mathrm{NO}_{3}{ }^{-}\right)$from manure usually takes a few weeks $[32,33]$. The previous studies have demonstrated the combination of organic manure and urea showed a significant positive effect on $\mathrm{N}_{2} \mathrm{O}$ flux $[34,35]$. Besides, $\mathrm{N}_{2} \mathrm{O}$ emission tended to be larger in receiving nitrogen 

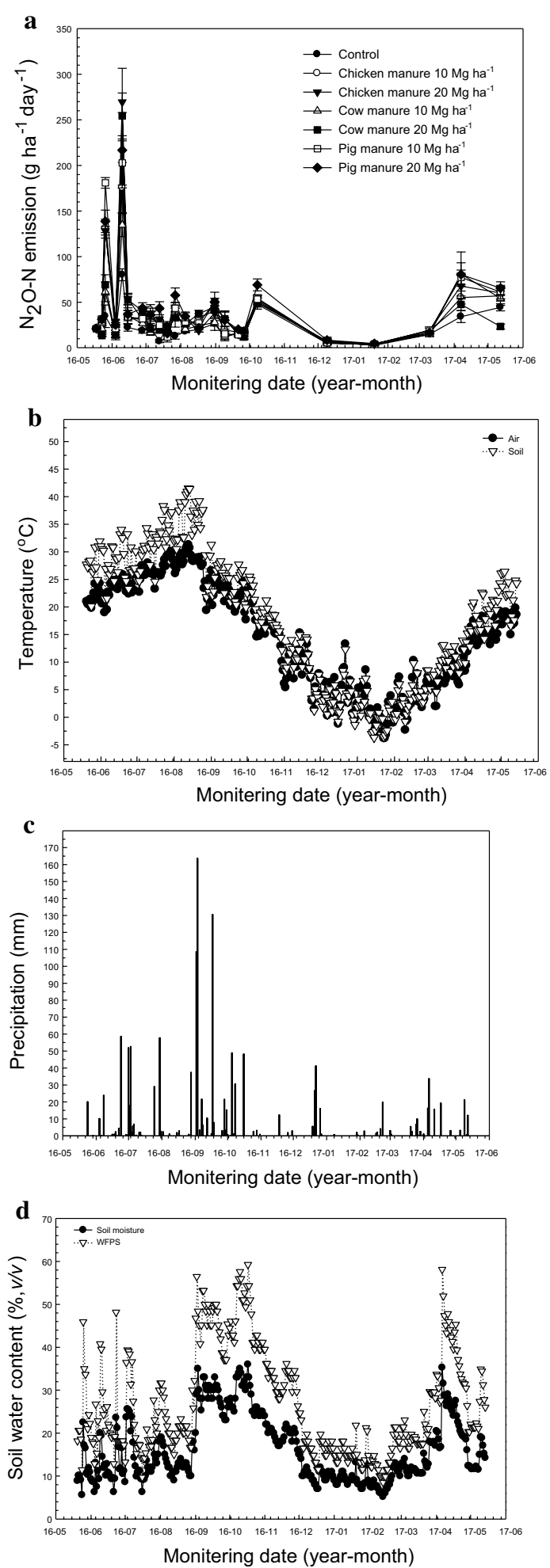

Fig. $1 \quad \mathrm{~N}_{2} \mathrm{O}-\mathrm{N}$ emission flux (a), air and soil temperature (b), precipitation (c), and soil moisture and WFPS (d) after application of different rates of animal manures for 1 year source treatments than in the unfertilized treatment [36, 37]. Hence, higher soil $\mathrm{NH}_{4}{ }^{+}$and $\mathrm{NO}_{3}{ }^{-}$availability proceed as substrate of microbial formation of $\mathrm{N}_{2} \mathrm{O}$ by the nitrification and denitrification processes [38]. Therefore, the source of $\mathrm{N}_{2} \mathrm{O}$ emission in the first observed peak might be attributed to inherent inorganic $\mathrm{N}$ in animal manure [33, 39]. As shown in Table 2, concentrations of $\mathrm{NH}_{4}{ }^{+}$and $\mathrm{NO}_{3}{ }^{-}$in animal manures ranged from 147 to $4638 \mathrm{mg} \mathrm{kg}^{-1}$ and 3.97 to $120 \mathrm{mg} \mathrm{kg}^{-1}$, respectively. Pig manure contained the highest concentration of $\mathrm{NH}_{4}{ }^{+}$ among the studied animal manures, and this contributed to the greatest $\mathrm{N}_{2} \mathrm{O}$ flux measured following pig manure treatment on 26th May (Fig. 1a). Urea was applied to the soil on 6th June and a second $\mathrm{N}_{2} \mathrm{O}$ peak occurred 4 days later on 10th June. This peak was greater than the first observed peak associated with manure application and might be due to the more rapid release of inorganic $\mathrm{N}$ from urea than from manure.

Daily climate data, including temperature, precipitation, and soil water content, were measured for 1 year to examine the relationship between climate data and $\mathrm{N}_{2} \mathrm{O}$ flux (Fig. 1b-d). No significant increase was seen in $\mathrm{N}_{2} \mathrm{O}$ flux when air and soil temperatures were highest in August, but fluxes were dramatically decreased when air and soil temperatures were lowest (in December and January). Nitrification and denitrification processes are slowed when the soil temperature is below 5 and $2{ }^{\circ} \mathrm{C}$, respectively [32]. In this study, soil temperature was below $5{ }^{\circ} \mathrm{C}$ from December to March and below $2{ }^{\circ} \mathrm{C}$ from January to February (Fig. 1b).

Precipitation and soil water content affected daily $\mathrm{N}_{2} \mathrm{O}$ fluxes during the non-growing season. $\mathrm{N}_{2} \mathrm{O}$ emissions peaked twice, once in November and again in April, even without the addition of $\mathrm{N}$ to the soil. Interestingly, WFPS slightly exceeded $60 \%$ only in November and April (Fig. 1d). Similar results were observed by Dobbie and Smith [40] who reported that peak of $\mathrm{N}_{2} \mathrm{O}$ fluxes only took place at $>60 \%$ of WFPS and significant relationship between WFPS and $\mathrm{N}_{2} \mathrm{O}$ flux was found. The soil's WFPS could be a useful indicator of the relative potential for aerobic and anaerobic microbial activity in soil [41]. Microbially driven nitrification and denitrification are particularly influenced by WFPS [42]. High $\mathrm{O}_{2}$ concentrations are known to suppress the activity and synthesis of the denitrification reductases. The $\mathrm{N}_{2} \mathrm{O}$ reductase is thought to be the most sensitive to $\mathrm{O}_{2}$ [43].

Mean cumulative $\mathrm{N}_{2} \mathrm{O}$ emissions were highest from soil amended with pig manure across application rates (Table 3). This might be attributed to the higher $\mathrm{NH}_{4}{ }^{+}$ concentrations measured in pig manure compared with chicken and cow manure (Table 2). As shown in Fig. 2a-c, relatively higher concentrations of $\mathrm{NH}_{4}{ }^{+}$in soil amended with pig manure were maintained during 
the growing season when compared with soil amended with chicken and cow manure. Daily $\mathrm{N}_{2} \mathrm{O}$ fluxes were higher in soil amended with pig manure from 6th July to 7 th October than in soil treated with chicken and cow manure (Fig. 1a). In contrast, $\mathrm{NO}_{3}{ }^{-}$concentrations were not higher in soil amended with pig manure during the growing season (Fig. $2 \mathrm{~d}-\mathrm{f}$ ). The relationship between daily $\mathrm{N}_{2} \mathrm{O}$ emission and inorganic $\mathrm{N}$ concentration in soil during the growing season (Fig. 3) implies the majority of $\mathrm{N}_{2} \mathrm{O}$ measured in this study could be from aerobic nitrification. The relationship between daily $\mathrm{N}_{2} \mathrm{O}$ emissions and the $\mathrm{NH}_{4}{ }^{+}$concentration in soil was significantly positive in this study, but no significant relationship was seen between daily $\mathrm{N}_{2} \mathrm{O}$ emission and $\mathrm{NO}_{3}{ }^{-}$concentration in soil. Nitrification is the primary pathway of $\mathrm{N}_{2} \mathrm{O}$ emission

Table 3 Cumulative $\mathrm{N}_{2} \mathrm{O}-\mathrm{N}$ emission from soils amended with different rates of animal manures

\begin{tabular}{lccc}
\hline $\begin{array}{l}\text { Application rate } \\
\left(\mathbf{M g ~ h a}^{-1}\right)\end{array}$ & \multicolumn{2}{l}{ Animal manure } & \\
\cline { 2 - 4 } & Chicken & Cow & Pig \\
\hline Cumulative $\mathrm{N}_{2} \mathrm{O}-\mathrm{N}^{2}$ emission $\left(\mathrm{kg} \mathrm{ha}^{-1}\right.$ year $\left.^{-1}\right)$ & & \\
0 & $7.96^{\mathrm{C}}$ & $7.96^{\mathrm{b}}$ & $7.96^{\mathrm{C}}$ \\
10 & $11.4^{\mathrm{b}}$ & $10.8^{\mathrm{a}}$ & $13.1^{\mathrm{b}}$ \\
20 & $13.1^{\mathrm{a}}$ & $11.5^{\mathrm{a}}$ & $14.7^{\mathrm{a}}$ \\
Mean & $10.8^{\mathrm{B}}$ & $10.1^{\mathrm{C}}$ & $11.9^{\mathrm{A}}$ \\
\hline
\end{tabular}

${ }^{1}$ Mean: mean value across application rates. Upper and lower case letters are for column and row comparison. Values with the same letter within a column or row are not significantly when soil's WFPS ranges from 30 to $60 \%$, while denitrification is the major process when soil's WFPS is $>60 \%$ [44, 45]. The WFPS of the soil we studied was mostly less than $60 \%$ during the growing season; therefore, we assumed the majority of $\mathrm{N}_{2} \mathrm{O}$ was produced from aerobic nitrification. In addition, $\mathrm{N}_{2} \mathrm{O}$ emissions resulting from nitrification during the growing season might be governed by the $\mathrm{NH}_{4}{ }^{+}$concentration in animal manure rather than by the total $\mathrm{N}$ concentration in this study.

DOC released from composted animal manure could be a source of available $C$ for use by microorganisms in the denitrification process in soil. Haung et al. [8] reported that cumulative emission of $\mathrm{N}_{2} \mathrm{O}$ was positively correlated with DOC concentration in soil. As shown in Fig. 4, mean values of DOC in soil increased as the manure application rate increased. DOC concentration was relatively higher in soil amended with chicken manure than in soils amended with cow and pig manure. This might be attributed to higher DOC concentrations in chicken manure than in cow and pig manure (Table 2). DOC concentration in manures, from the highest to the lowest, was chicken $>$ cow $>$ pig. However, cumulative $\mathrm{N}_{2} \mathrm{O}-\mathrm{N}$ emission rates ranked from the highest to the lowest were pig $>$ chicken $>$ cow (Table 3). This implied that DOC concentration in animal manures and soil might not affect $\mathrm{N}_{2} \mathrm{O}$ soil emissions, and this lack of a relationship was confirmed by correlation coefficient $(r=0.0004)$ (data not shown). High $\mathrm{O}_{2}$ content in the soil we studied might alleviate the effect of DOC on the denitrification process.
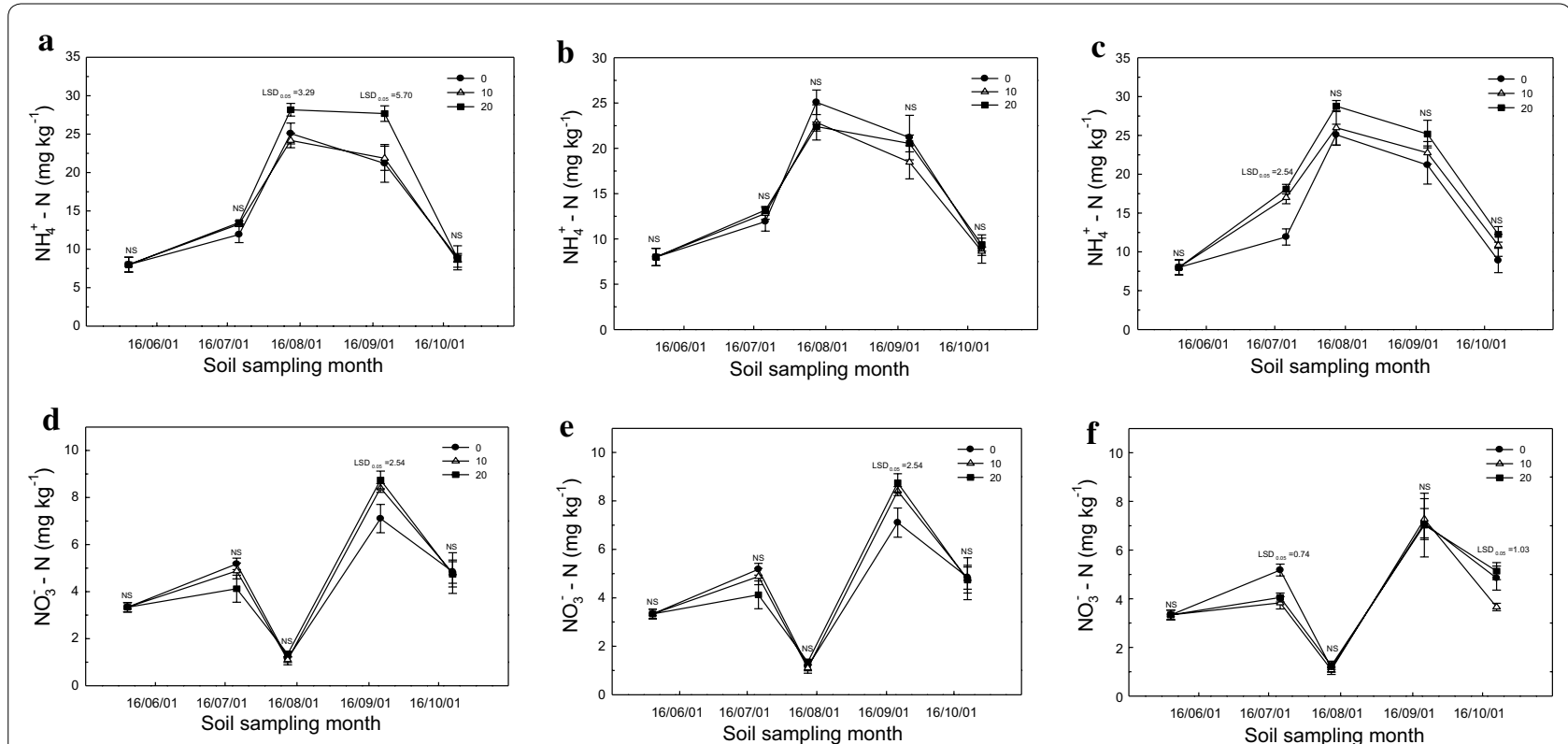

Fig. 2 Changes in inorganic $\mathrm{N}$ concentrations in soil amended with different rates of animal manures during the growing season of sweet potato a, d chicken manure, $\mathbf{b}$, e cow manure, and $\mathbf{c}$, $\mathbf{f}$ pig manure 

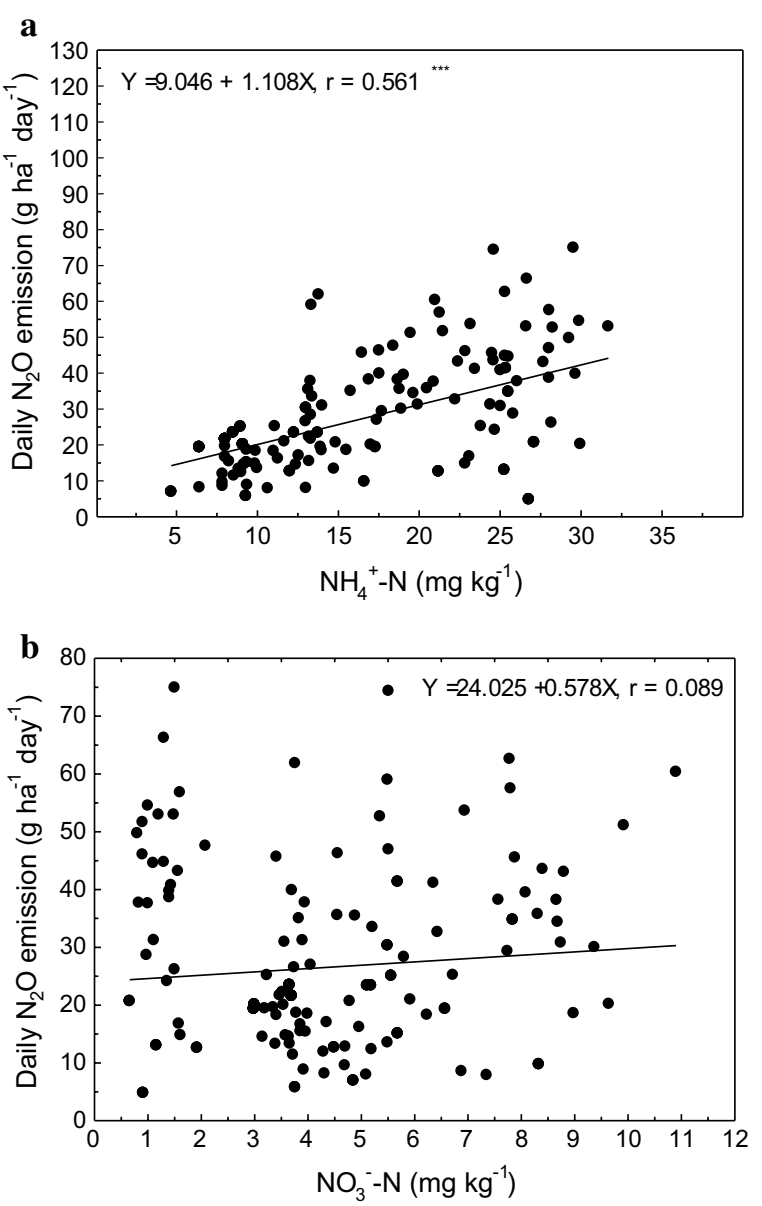

Fig. 3 Relationships between $\mathrm{NH}_{4}{ }^{+}$concentration in soil and daily $\mathrm{N}_{2} \mathrm{O}$ emission (a) and $\mathrm{NO}_{3}{ }^{-}$concentration in soil and daily $\mathrm{N}_{2} \mathrm{O}$ emission (b) during the growing season of sweet potato

As noted earlier, our soil had a WFPS typically $<60 \%$ throughout the growing season (Fig. 1d). Therefore, we assumed the majority of $\mathrm{N}_{2} \mathrm{O}$ was produced from aerobic nitrification rather than by denitrification. Even though the application of manure provided a $\mathrm{C}$ source for microbial denitrification, high $\mathrm{O}_{2}$ concentrations in soil pores might have suppressed the activity and synthesis of the denitrification reductases [43].

Cumulative $\mathrm{N}_{2} \mathrm{O}$ emissions during 1 year significantly increased with increasing application rate of all animal manures (Table 3). This increase might be related to change in MNR and ANR by sweet potato with increasing manure application rates. Surplus $\mathrm{N}$ in the soil beyond plant requirements might have more opportunity to be converted into $\mathrm{N}_{2} \mathrm{O}$. There was no significant increase in MNR with increasing application rates from 10 to $20 \mathrm{Mg} \mathrm{ha}^{-1}$ in all animal manures (Fig. 5a-c). In addition, ANR in chicken manure and pig manure treatments significantly decreased with increasing application
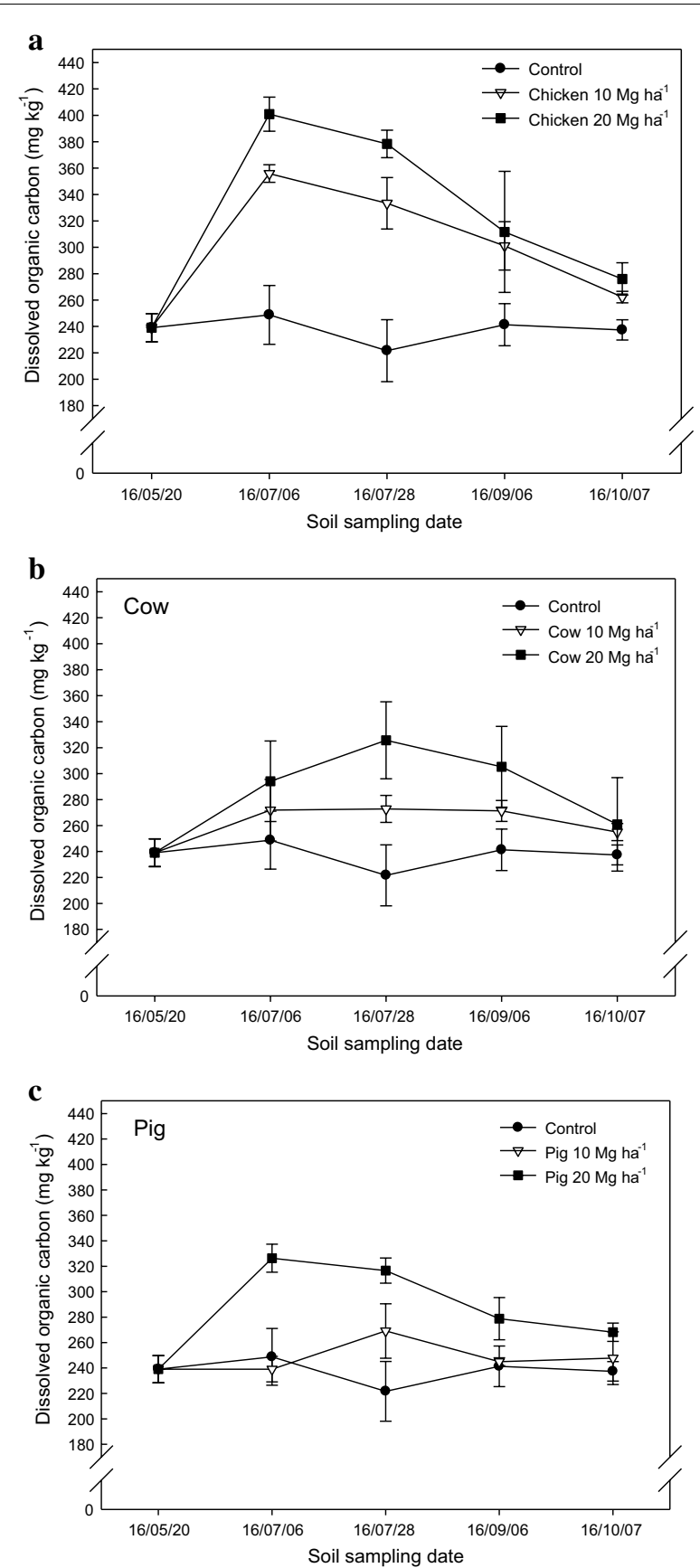

Fig. 4 Changes in DOC concentration in soil amended with different rates of animal manures during the growing season of sweet potato a chicken manure, $\mathbf{b}$ cow manure, and $\mathbf{c}$ pig manure

rates (Fig. 5d, f), but there was no significant difference observed between all application rates of cow manure (Fig. 5e). These results mimicked the cumulative $\mathrm{N}_{2} \mathrm{O}$ emissions shown in Table 3. Cumulative $\mathrm{N}_{2} \mathrm{O}$ emission significantly increased with increasing application rates of chicken and pig manure from 10 to 20 $\mathrm{Mg} \mathrm{ha}{ }^{-1}$, but significant increases were not observed 

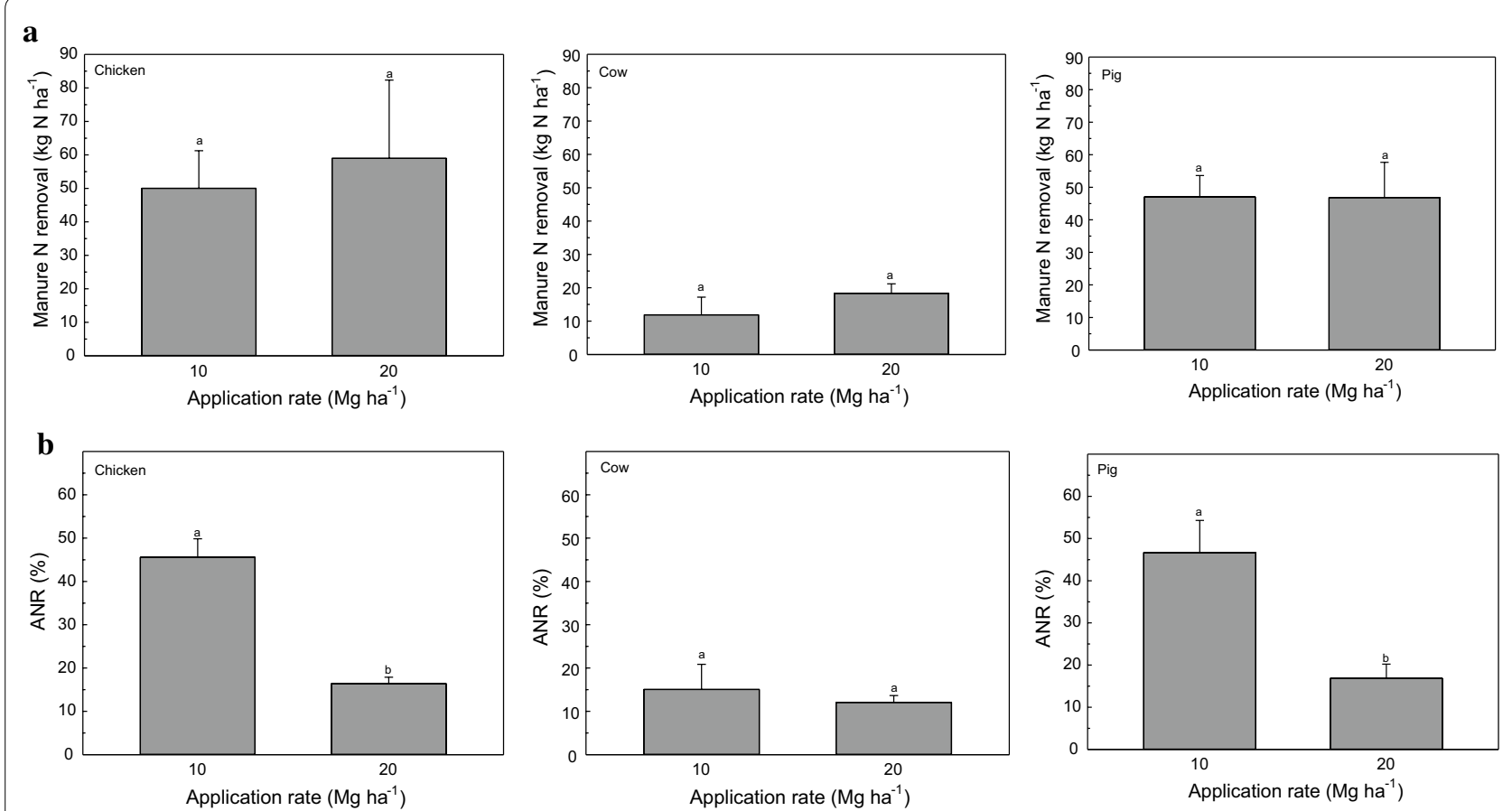

Fig. 5 Manure N removal (a) and ANR (b) of sweet potatoes grown in soils amended with different rates of animal manures at harvest time

when the application rate of cow manure was increased. This implies that excess $\mathrm{N}$ in soil amended with animal manures may be lost through $\mathrm{N}_{2} \mathrm{O}$ emission.

\section{Authors' contribution}

SUK, CR, HHL, and HJP carried out gas and soil sampling, gas and soil analyses, and data organization. SUK, SK, ESJ, and COH participated in interpreting the obtained results and organizing the manuscript. All authors read and approved the final manuscript.

\section{Author details}

${ }^{1}$ Department of Life Science and Environmental Biochemistry, Pusan National University, Miryang 50463, Republic of Korea. ${ }^{2}$ Plant Science Department, South Dakota State University, 1110 Rotunda Lane North, Brookings, SD 57007, USA. ${ }^{3}$ Department of Bioenvironmental Energy, Pusan National University, Miryang 50463, Republic of Korea. ${ }^{4}$ Life and Industry Convergence Research Institute, Pusan National University, Miryang 50463, Republic of Korea.

\section{Acknowledgements}

This study was carried out with the support of "Research Program for Agricultural Science \& Technology Development (Project No. PJ01 185504)," National Academy of Agricultural Science, Rural Development Administration, Republic of Korea.

\section{Competing interest}

The authors declare that they have no competing interests.

\section{Publisher's Note}

Springer Nature remains neutral with regard to jurisdictional claims in published maps and institutional affiliations.

Received: 8 October 2018 Accepted: 21 January 2019

Published online: 28 February 2019

\section{References}

1. Syalila A, Kroeze C (2011) The global nitrous oxide budget revisited. Greenh Gas Meas Manag 1:17-26

2. Lee DJ, Yoon YM, Choi IW, Bae JS, Seo DC (2017) Effect of seasonal variations of organic loading rate and acid phase on methane yield of food waste leachate in South Korea. Appl Biol Chem 60:87-93

3. Park W, Kim KS, Lee JE, Cha YL, Moon YH, Song YS, Jeong EG, Ahn SJ, Hong SW, Lee YH (2017) Effect of different application levels of rapeseed meal on growth and yield components of rice. Appl Biol Chem 60:403-410

4. Granli T, Bockman OC (1994) Nitrogen oxide from agriculture. Nor J Agric Sci 12:7-127

5. Cabrera ML, Chiang SC, Merka WF, Pancobo OC, Thompson SA (1994) Nitrous-oxide and carbon-dioxide emissions from pelletized and non pelletized poultry litter incorporated into soil. Plant Soil 163:189-195

6. Chadwick D, John F, Pain B, Chambers B, Williams J (2000) Plant uptake of nitrogen from the organic nitrogen fraction of animal manures: a laboratory experiment. J Agric Sci 134:159-168

7. Chadwick DR, Pain BF, Brookman SKE (2000) Nitrous oxide methane emissions following application of animal manures to grassland. J Environ Qual 29:277-287

8. Huang Y, Zou J, Zheng X, Wang Y, Xu X (2004) Nitrous oxide emissions as influenced by amendment of plant residues with different $\mathrm{C}: \mathrm{N}$ ratios. Soil Biol Biochem 36:973-981

9. Dittert K, Lampe C, Gasche R, Butterbach-Bahl K, Wachendorf M, Papen H, Sattelmacher B, Taube F (2005) Short-term effects of single or combined application of mineral $\mathrm{N}$ fertilizer and cattle slurry on the fluxes of radiatively active trace gases from grassland soil. Soil Biol Biochem 37:1665-1674

10. Wei-xin D, Lei M, Zu-cong CAl, Feng-xiangc HAN (2007) Effects of longterm amendment of organic manure and nitrogen fertilizer on nitrous oxide emission in a sandy loam soil. J Environ Sci 19:185-193

11. Chantigny MH, Rochette P, Angers DA, Bittman S, Buckely K, Masse D, Belanger G, Eriksen-Hamel N, Gasser M-O (2010) Soil nitrous oxide emissions following band-incorporation of fertilizer nitrogen and swine manure. J Environ Qual 39:1545-1553 
12. Dalal RC, Gibson I, Allen DE, Menzies NW (2010) Green waste compost reduces nitrous oxide emissions from feedlot manure applied to soil. Agric Ecosyst Environ 136:273-281

13. Liu Z, Powers W (2012) Meta-analysis of greenhouse gas emissions from swine manure land application. In: American society of agricultural and biological engineers annual international meeting 2012, ASABE. United States, pp 3829-3843

14. Bouwman AF (1996) Direct emissions of nitrous oxide from agricultural soils. Nutr Cycl Agroecosyst 46:53-70

15. Brown HA, Waggner-Riddle C, Thurtell GW (2000) Nitrous oxide flux from solid dairy manure in storage as affected by water content and redox potential. J Environ Qual 29:630-638

16. Maggiotto SR, Webb JA, Waggner-Riddle C, Thurtell GW (2000) Nitrous and nitrogen oxide emissions from turfgrass receiving different forms of nitrogen fertilizer. J Environ Qual 29:621-630

17. Daum D, Schenk MK (1998) Influence of nutrient solution $\mathrm{pH}$ on $\mathrm{N}_{2} \mathrm{O}$ and $\mathrm{N}_{2}$ emissions from a soilless culture system. J Plant Soil 203:279-287

18. Mogge B, Kaiser EA, Munch JC (1999) Nitrous oxide emissions and denitrification $\mathrm{N}$-losses from agricultural soils in the Bornho"ved lake region: influence of organic fertilizers and land-use. Soil Biol Biochem 31:1245-1252

19. Schindlbacher A, Zechmeister-Boltenstern S, Butterbach-Bahl K (2004) Effects of soil moisture and temperature on $\mathrm{NO}, \mathrm{NO}_{2}$, and $\mathrm{N}_{2} \mathrm{O}$ emissions from European forest soils. J Geophys Res Atmos 109(D17):302-313

20. Butterbach-Bahl K, Baggs EM, Dannenmann M, Kiese R, ZechmeisterBoltenstern S (2013) Nitrous oxide emissions from soils: how well do we understand the processes and their controls? Philos Trans R Soc B Biol Sci 368(1621):122-134

21. Boyer JN, Groffman PM (1996) Bioavailability of water extractable organic carbon fractions in forest and agricultural soil profiles. Soil Biol Biochem 28:783-790

22. Yano Y, McDowell WH, Aber JD (2000) Biodegradable dissolved organic carbon in forest soil solution and effects of chronic nitrogen deposition. Soil Biol Biochem 32:1743-1751

23. Rochette P, Angers DA, Cote D (2000) Soil carbon and nitrogen dynamics following application of pig slurry for the 19th consecutive year: I. Carbon dioxide fluxes and microbial biomass carbon. Soil Sci Soc Am J 64:1389-1395

24. Paul JW, Beauchamp EG, Zhang X (1993) Nitrous and nitric oxide emissions during nitrification and denitrification from manure-amended soil in the laboratory. Can J Soil Sci 73:539-553

25. Velthof GL, Kuikman PJ, Oenema O (2003) Nitrous oxide emission from animal manures applied to soil under controlled conditions. Biol Fertil Soils 37:221-230

26. Parkin TB, Venterea RT (2010) Chamber-based trace gas flux measurements. USDA-ARS GRACE net project protocols, USDA, Beltsville, MD 1-39

27. Kamphake LJ, Hannah SA, Cohen JM (1967) Automated analysis for nitrate by hydrazine reduction. Water Res 1:205-216

28. Searle PL (1984) The berthlot or indophenol reaction and its use in the analysis chemistry of nitrogen. Analyst 109:549-565

29. Kim SU, Owens VN, Kim SY, Hong CO (2017) Effect of different way of bottom ash and compost application on phytoextractability of cadmium in contaminated arable soil. Appl Biol Chem 60:353-362
30. Owens VN, Viands DR, Mayton HS, Fike JH, Farris R, Heaton E, Bransby DI, Hong CO (2013) Nitrogen use in switchgrass grown for bioenergy across the USA. Biomass Bioenergy 58:286-293

31. Ozlu E, Kumar S (2018) Response of surface GHG fluxes to long-term manure and inorganic fertilizer application in corn and soybean rotation. Sci Total Environ 626:817-825

32. Brady NC, Weil RR (2010) Elements of the nature and properties of soils. Pearson, Boston

33. Afreh D, Zhang J, Guan D, Liu K, Song Z, Zheng C, Deng A, Feng Z, Zhang X, Wu Y, Huang Q, Zhang W (2018) Long-term fertilization on nitrogen use efficiency and greenhouse gas emissions in a double maize cropping system in subtropical China. Soil Tillage Res 180:259-267

34. Das S, Adhya TK (2014) Effect of combine application of organic manure and inorganic fertilizer on methane and nitrous oxide emissions from a tropical flooded soil planted to rice. Geoderma 213:185-192

35. Kuang W, Gao X, Gui D, Tenuta M, Flaten DN, Yin M, Zeng F (2018) Effects of fertilizer and irrigation management on nitrous oxide emission from cotton fields in an extremely arid region of northwestern China. Field Crops Res 229:17-26

36. Watanabe A, Ikeya K, Kanazaki N, Makabe S, Sugiura Y, Shibata A (2014) Five crop season' records of greenhouse gas fluxes from upland fields with repetitive applications of biochar and cattle manure. J Environ Manag 144:168-175

37. Yuan Y, Chen H, Yuan W, Williams D, Walker JT, Shi W (2017) Is biocharmanure co-compost a better solution for soil health improvement and $\mathrm{N}_{2} \mathrm{O}$ emissions mitigation? Soil Biol Biochem 113:14-25

38. Yao Z, Yan G, Zheng X, Wang R, Liu C, Butterbach-Bahl K (2017) Reducing $\mathrm{N}_{2} \mathrm{O}$ and $\mathrm{NO}$ emissions while sustaining crop productivity in a Chinese vegetable-cereal double cropping system. Environ Pollut 231:929-941

39. Mori A, Hojito M (2012) Effect of combined application of manure and fertilizer on $\mathrm{N}_{2} \mathrm{O}$ fluxes from a grassland soil in Nasu, Japan. Agr Ecosyst Environ 160:40-50

40. Dobbie K, Smith K (2003) Nitrous oxide emission factors for agricultural soils in Great Britain: the impact of soil water-filled pore space and other controlling variables. Glob Change Biol 9:204-218

41. Linn DM, Doran JW (1984) Effect of water-filled pore space on carbon dioxide and nitrous oxide production in tilled and nontilled soils. Soil Sci Soc Am J 48(6):1267-1272

42. Westphal M, Tenuta M, Entz MH (2018) Nitrous oxide emissions with organic crop production depends on fall soil moisture. Agr Ecosyst Environ 254:41-49

43. Otte S, Grobben NG, Robertson LA, Jetten MSM (1996) Nitrous oxide production by Alcaligens faecalis under transient and dynamic aerobic and anaerobic conditions. Appl Environ Microbiol 39:2421-2426

44. Bateman EJ, Baggs EM (2005) Contributions of nitrification and denitrification to $\mathrm{N}_{2} \mathrm{O}$ emissions from soils at different water-filled pore space. Biol Fertil Soils 41:379-388

45. Kool DM, Dolfing J, Wrage N, van Groenigen JW (2011) Nitrifier denitrification as a distinct and significant source of nitrous oxide from soil. Soil Biol Biochem 43:174-178

\section{Submit your manuscript to a SpringerOpen ${ }^{\circ}$ journal and benefit from:}

- Convenient online submission

- Rigorous peer review

- Open access: articles freely available online

- High visibility within the field

Retaining the copyright to your article

Submit your next manuscript at springeropen.com 